MEYER, OTTO.-Entzundliche Jugularstenose als Ursache des primaeren Glaukoms. Schweiz. Med. Wchnschr. May 11, 1946.

-Incidence and significance of infected tonsil remnants. The Eye, Ear, Nose and Throat Monthly, Vol. XXV, pp. 244-246. May, 1946.

Roessle.-Ueber Fokalinfektion. Verh. d. deutsch. Gesellsch. f. Innere Med., Vol. LI, p. 423. 1939.

SCHOENBERG, M. J.-Remarks on artificial induction of ocular hypertension by compression of the jugular veins. Arch. Ophthal., Vol. I, pp. 681-691. June, 1929.

SEIDEL.-Experimentelle Untersuchungen ueber intraokulaere Saftstoerung : IX. Ueber den Abfluss des Kammerwassers. Arch. f. Ophthal., Vol. CIV, p. 357. 1921.

-Ueber den manometrischen Nachweis des physiologischen Druckgefaelles zwischen Vorderkammer und Schlemmschen Kanal. Graefe's Arch., Vol. CVII, p. 101 . 1921-1922.

Siegmund, H.- - Ueber die akute Phlebitis der Halsvenen bei odontogenen Kiefererkrankungen als Ausgang septischer Allgemein-Infektionen. Deitsche Zahn-, Mund-, u. Kieferheilk., Vol. LXXIV, pp. 56-61. 1929.

- Pathologish-anatomische Befunde an dentalen Kieferherden bei pulpenlosen Zaehnen mit Bemerkungen zur Frage der chronischen Tonsillitis. Verhandl. d. Deutsch. Gesellsch. f. Innere Med., Vol. LI, p. 544. 1939.

WALDAPFEL. - Zur Klinik und Therapie der Sepsis nach Angina. Wien. Klin. Wochnschr., Vol. XLVIII, p. 136. Feb. 1, 1935.

WASSMUND, M.-Ueber fokale Infektion. Zentralbl. f. Chir., Vol. LXII, p. 2161, 1935.

\title{
OCULAR LESIONS IN INTERNEES AT A CIVILIAN INTERNMENT CAMP AT HONG KONG*
}

\author{
BY \\ H. TALBOT \\ HONG KONG
}

Amongst the inmates at a Civilian Internment Camp at Stanley, Hong Kong, a number of ocular symptoms were observed during the Japanese occupation. The general conditions prevailing in the camp were none too good. Food was not plentiful; there were only two meals a day. After about the first year in camp meat was not included in the dietary, except on three or four occasions. Towards the last month of internment water-buffalo (? horse) was supplied. Fish, usually as fresh raw fish, or as dried-salted, was not frequently given, and when 'supplied it was always in small quantities.

During the three and three-quarter years' internment everybody received four Red Cross parcels; a number of internees, perhaps 40 per cent. in the early days dwindling to 10 per cent. or less later on, received parcels of food from friends (Chinese and third Nationals) living in Hong Kong. In the early days it was possible to augment the rations with food bought at the canteen,

\footnotetext{
* Received for publication, June 13, 1946.
} 
but these extras ceased with the growth of the black marketrun by the Japanese guards through their British contacts, internees in the camp. In the last six to nine months of internment, the black market prices became so prohibitive that most people were unable to obtain any extra food.

Two hundred and seventy-eight internees (designated Group A) developed obvious ocular symptoms for which they attended the eye clinic, or were referred to it by the Nutrition Clinic attached to the camp. To assess the significance of these symptoms 111 consecutive patients attending the Nutrition Clinic for some deficiency condition, but not complaining of ocular symptoms, were studied as a control series (designated as Group B). Field defects and subjective symptoms were the outstanding conditions observed.

\section{1.-Field defects}

In the 278 patients with ocular symptoms the most constant objective finding was constriction of the peripheral fields for white, red and black. In a few cases the fields for white were so constricted that only a small central area of vision was left, and the patients stated that they seemed to be looking through binoculars. In such patients no field for black or red could be determined at all. These cases are, therefore, similar to those described by Wilkinson and King where central or paracentral scotoma to white, black or red was the exception, whilst loss of the peripheral field was outstanding. In no case was there contraction of the field for white without concomitant contraction for red, or red and black, and no case showed contraction for black without an equally or greater contraction for red. The field for red was always the first to be affected, and with increasing contraction of the red field, field defects for black and white became apparent. The following table (Table 1) shows the percentage distribution of field defects in this group.

\section{TABLE I}

\begin{tabular}{|c|c|c|}
\hline Colour & Contracted & Normal \\
\hline$\left\{\begin{array}{l}\text { Red alone } \\
\text { Red and black }\end{array}\right.$ & $\left.\begin{array}{r}85(31 \text { per cent. }) \\
193(69 \text { per cent. })\end{array}\right\}$ & - \\
\hline White & 227 (82 per cent.) & $5 \mathrm{i}$ (18 per cent.) \\
\hline
\end{tabular}

In patients with ocular symptoms contraction of the field for red, or red and black, was therefore a constant feature, whilst no less than 82 per cent. of such patients showed contraction of the field for white. 
There was also a considerable incidence of field defects in the control series of 111 cases. The percentage distribution is shown by the following table.

\section{TABLE II.}

\begin{tabular}{|c|c|c|}
\hline Colour & Contracted & Normal \\
\hline $\begin{array}{l}\text { Red } \\
\text { Red and black }\end{array}$ & 88 (79 per cent.) & 23 (21 per cent.) \\
\hline Red alone & 47 ( 42 per cent. of total) & - \\
\hline Black : & 39 (35 per cent. of total) & - \\
\hline White & 48 (44 per cent.) & 63 (56 per cent.) \\
\hline
\end{tabular}

Central scotoma for colours was rare. There were seven cases in Group A and none in Group B.

\section{2.-Fundus lesions}

In Group $A$ the commonest finding was pallor of the lower temporal quadrant of the disc, which in progressive cases extended so that ultimately it gave a typical picture of optic atrophy.

Only two patients in the control series were examined, and of these one showed pallor in the lower temporal quadrant of the disc.

\section{3.-Conjunctival lesions}

In Group A conjunctival involvement was fairly common, mainly in the lower palpebral conjunctiva and fornix giving a picture not unlike that of spring catarrh. Only occasionally were the upper fornices involved. Xerosis was present in a number of cases wih Bitôt's spots in twelve patients. Mild circumcorneal injection, not unlike a mild iridic injection, was seen in a number of cases.

\section{4.-Subjective symptoms}

(a) Headaches. In 177 patients in Group A (64 per cent.) headaches occurred as frontal, occipital, bulbar and retrobulbar ache. There did not appear to be any general relationship between the headaches and objective findings, except that in the more advanced cases the headaches were constant.

(b) Disturbances in visual perception. These took the form of " flicker" or movements of objects, and referred to by the patients as a " jumping" or " jiggling" of the letters, etc., of " seeing objects as through a mosquito net" or "through a window-pane 
covered with rain drops," "objects come into focus, then disappear," " they come and go," etc. Movements at the periphery of the field occurred in some instances.

(c) Temporary loss of vision. Sixteen patients in Group A (6 per cent.) had temporary loss of vision lasting for a matter of minutes to half an hour. On examination nothing abnormal could be detected ophthalmoscopically. The degree of loss of vision varied: in every case it was unilateral and was in only three cases complete for the affected eye. In the others, only " parts of objects" were seen and after a short period, the vision cleared and the complete object was discernable. All of these cases examined objectively showed some contraction of the fields for white and colours, and some temporal pallor of the disc.

(d) Night blindness. This was a common feature and in a number of cases led to minor injuries-the patients walking into objects or tripping over stones and steps. One patient with restricted fields and marked night blindness was constantly running into things.

(e) Impaired central vision. This was surprisingly exceptional. In Group A only 47 had visual acuity of less than 6/12 with the two eyes together. In Group B 23 patients had impaired central vision.

(f) Glare. This was a common complaint in both groups.

(g) Eye strain. This, and the symptoms of headaches appear to go together. Fatigue of the external muscles showed itself by such complaints as heaviness of the lids presumably from inefficiency of the levator palpebrae superioris. Patients found themselves unable to keep their lids open, and were actually seen supporting their upper lids, particularly towards the end of the day. In two patients a marked ptosis developed, which improved after injections of thiamin.

\section{Treatment}

In Group A seven patients were treated with riboflavin, $5 \mathrm{mgm}$. daily for 30 days. There was no improvement in any of them objectively, but five patients stated that they felt much better in themselves. It seems probable that the dosage was much too small but it represents practically the total amount of riboflavin that was available. Patients were treated with nicotinic acid, thiamin, shark liver oil and yeast-either singly or in combination. But no one therapeutic agent effected any marked improvement. The doses tended to be small because of the small quantities available and proteins and fats were lacking. The patients who seemed to benefit most were those who were in a position to obtain eggs and fats and there were some instances of quite dramatic 
improvement where visual acuity had gone down to $6 / 60$ and fields were contracted down to around the central area. After a course of eggs and fats visual acuity improved to 6/12. About half the cases (Group A) were given yeast daily, but it was recognised as of poor therapeutic quality.

An earlier series of cases had been treated with foods of high protein and vitamin content (eggs, liver paste, peanut butter). These patients subsequently came under the care of the present writer. Some showed a further slight improvement, but the majority remained unchanged, and a number deteriorated.

From a survey of the periodic examination it would seem that the objective findings when the patients first presented themselves were more or less the maximum of involvement, with a tendency to slow deterioration.

The presence of avitaminosis and gross nutritional deficiency in all these cases leads to the suggestion that aetiologically the ocular symptoms were of nutritional origin. These symptoms did not seem to depend on the absence of any one particular vitamin, but rather to an imbalance with or without an absolute lack of either vitamin A or B1 or B2 complex. Closely associated with the abnormal balance of vitamins in the diet was the lack of proteins and fats and absence of these, too, doubtless played their part in producing the final clinical picture.

Taken as a whole the ocular symptoms, particularly the field defects, suggest that primarily the lesions observed-whatever their cause-were retinal in origin rather than nerve lesions. Such a reading forces itself from a study of the field defects.

I take this opportunity of thanking and placing on record the able work and the immense patience shown by Mr. W. C. Walker (Hong Kong Govt. Dept.) who, over a period of about three and a half years in the camp, carried out practically all the examinations of the fields.

\title{
BILATERAL PARTIAL COLOBOMA OF THE OPTIC NERVE
}

BY

\author{
JOHN A. MAGNUS \\ YOR K
}

Соцовома of the optic nerve, without involvement of the choroid, is such a rare condition that I feel justified in adding this case to those odd fifty already reported in the literature which was recently reviewed by $T$. Steinberg of San Francisco. 